\title{
Production of Interleukins in Human Immunodeficiency Virus-1-replicating Lymph Nodes
}

\author{
D. Emilie, M. Peuchmaur, ${ }^{\star}$ M. C. Maillot, M. C. Crevon, N. Brousse; ${ }^{\ddagger}$ J. F. Delfraissy, J. Dormont, and P. Galanaud \\ Institut National de la Santé et de la Recherche Médicale U131, Association Claude Bernard and Service de Médecine Interne, ${ }^{*}$ Service \\ d'Anatomie Pathologique, Hôpital A. Béclère, Clamart, 'Service d'Anatomie Pathologique, Hôpital Necker, Paris, France
}

\begin{abstract}
To document the in vivo interactions occurring between the immune system and HIV replicating cells, we analyzed using in situ hybridization the production of $I L-1 \beta, I L-6, I L-2$, and INF- $\gamma$ in eight hyperplastic lymph nodes from HIV-1 infected patients. Numerous IL-1 $\beta$ - and IL-6-producing cells associated in clusters were detected in sinuses. Few individual IL-1 $\beta$ - and IL-6-producing cells were present in interfollicular and follicular areas. IL-2- and INF- $\gamma$-producing cells were observed in all lymph node compartments, with a selective enrichment in germinal centers. The amount and distribution of IL-1 $\beta$-, IL-6-, and IL-2-producing cells in HIV lymph nodes were not different from those found in six HIV unrelated hyperplastic lymph nodes. In contrast, a higher level of INF- $\gamma$ production was observed in HIV-1 lymph nodes. The CD8+ cells that accumulate in germinal centers of HIV lymph nodes (and not in non-HIV germinal centers) were actively involved in this INF- $\boldsymbol{\gamma}$ production. INF- $\boldsymbol{\gamma}$ synthesizing cells were in direct contact with cells containing HIV core antigens and HIV RNA. Thus a high INF- $\gamma$ production may characterize antiHIV T cell immune response, potentially contributing to control of viral spreading as well as to the development of follicle lysis. (J. Clin. Invest. 1990. 86:148-159.) Key words: cytokines • HIV • AIDS • lymph node
\end{abstract}

\section{Introduction}

HIV infection leads to an acquired immunodeficiency syndrome mainly characterized by an unusual sensitivity to opportunistic infectious agents. However, the interval of time between the initial infection and the development of this immunodeficiency state can span several years. The mechanisms of transition from the asymptomatic state to immunodeficiency are only partially understood (reviewed in 1-3). The spread of HIV infection may be dependent on the rate of HIV replication as well as on stimulations of the immune system or coinfection with non-HIV viruses. In contrast, selective destruction of HIV replicating cells by the immune system may limit the progression of the disease. This anti-HIV immune response may also destroy uninfected cells coated with viral antigens $(2,4,5)$. This latter phenomenon could at least partially explain the dramatic decrease in CD4+ $T$ lymphocytes

Address reprint requests to Dr. Emilie, INSERM U 131, 32 rue des Carnets, 92140 Clamart, France.

Received for publication 7 July 1989 and in revised form 5 De cember 1989.

J. Clin. Invest.

(c) The American Society for Clinical Investigation, Inc.

0021-9738/90/07/0148/12 \$2.00

Volume 86, July 1990, 148-159 levels observed in the latest stages of the disease, and which play a pivotal role in the appearance of the immune defect.

Given the potential role of the immune system in both HIV infection control and HIV induced immune defect, the in vivo interactions between HIV replicating cells and immune cells should be defined. To this end, we analyzed using in situ hybridization the production of cytokines in lymph nodes from patients presenting persistent generalized lymphadenopathies (PGL). ${ }^{1}$ This synthesis of interleukins was compared to that of reactive lymph nodes from non-HIV-infected patients to define HIV-specific events.

\section{Methods}

Patients. Eight biopsy specimens from HIV-1 infected patients were included in this study. Two tissue samples (1a and $1 \mathrm{~b}$ ) obtained at 6-mo intervals were available for patient 1 . The diagnosis of HIV-1 infection was ascertained by the demonstration of anti-HIV-1 antibodies in two different serum samples using an ELISA immunoassay, and confirmed by Western blot analysis. The main clinical characteristics and laboratory findings of these patients at the moment of the biopsy are summarized in Table I. All of them exhibited PGL. Patients 3 and 7 presented a Kaposi sarcoma that did not involve lymph nodes. None of the seven patients presented opportunistic infection and only patient 3 had a major CD4+ T cell depletion. Serological analysis for anti-HTLV-1 antibodies was negative in the four patients tested (patients $1,2,5$, and 6 , thus including the three patients contaminated by intravenous drug abuse). There was no clinical or geographical argument suggesting an HTLV-1 coinfection in the three remaining patients.

As controls, six patients presenting lymph node enlargements of unknown origin without any evidence of HIV infection (including serological analysis) were studied.

Tissues. Lymph nodes were obtained at surgical biopsy. A portion of each specimen was immediately frozen in liquid nitrogen and stored at $-80^{\circ}$. In all cases tissue samples were also fixed in neutral formalin and processed for histological examination. Histological changes suggesting mycobacterial, herpes simplex virus, cytomegalovirus (CMV), or EBV infection (6) were observed in none of the tissue samples.

Detection of viral replication. Several approaches were performed to document viral replication in the lymph nodes studied. The detection of viral antigens was realized by immunohistochemistry using a three-step immunoperoxidase technique (7). The presence of HIV antigens was analyzed using an anti-p24 monoclonal antibody (clone 1 HIV, final dilution 1/75) (Biosoft, Paris, France). HIV-1 replication was also analyzed using in situ hybridization (see below). HSV 1 or 2 infection was assessed using an anti-HSV $1+2$ monoclonal antibody (clone CHA 437, final dilution: 1/400) (Biosoft). A lymph node exhibiting typical histological features of HSV infection was used as positive control. Detection of CMV antigens was performed using an anti-CMV early antigen monoclonal antibody (clone E13, final dilution: 1/100; Biosoft). CMV replicating cultured fibroblasts were ana-

1. Abbreviations used in this paper: CMV, cytomegalovirus; PGL, persistent generalized lymphadenopathies. 


\begin{tabular}{cccccccc}
\hline Patient & Age & $\begin{array}{l}\text { Grade } \\
\text { (CDC) }\end{array}$ & CD4+ & p24 antigenemia & $\begin{array}{c}\text { Anti-p24 } \\
\text { antibodies }\end{array}$ & Contamination & Histological pattern \\
\hline & $y r$ & & $/ \mu l$ & $p g / m l$ & & & \\
1 & 36 & III & 350 & 318 & + & Drug addict & Florid hyperplasia \\
2 & 22 & III & 476 & 287 & - & Blood transfusion & Florid hyperplasia \\
3 & 42 & IV D & 96 & - & + & Homosexual & Florid hyperplasia \\
4 & 30 & III & 492 & NT & NT & Homosexual & Florid hyperplasia \\
5 & 35 & IV D & 237 & 40 & + & Homosexual & Follicle lysis \\
6 & 26 & III & 782 & 169 & + & Drug addict & Follicle lysis \\
7 & 23 & III & 552 & 154 & - & Drug addict & Follicle lysis \\
\hline
\end{tabular}

NT, not tested.

lyzed as controls. An anti-EBV monoclonal antibody recognizing EBV nuclear antigens (clone $C$ 814) (final dilution: 1/100; Biosoft) was used to detect EBV infected cells, in vitro EBV-infected normal B lymphocytes being used as controls. The presence of CMV in HIV lymph nodes was also analyzed by viral cultures as previously described (8). Briefly, frozen tissue sections of HIV lymph nodes were crushed and cultured for $2 \mathrm{~d}$ in the presence of the $\mathrm{CMV}$ replicating fibroblast cell line MRC5. Detection of CMV antigens was then performed by immunostaining using the E13 monoclonal antibody. Serum samples from CMV-infected patients were used as positive controls in these experiments.

Probes. The IL-1 $\beta$ probe corresponded to the Pst-1-Acc-1 920 bp long fragment of the human IL-1 $\beta$ cDNA (9) cloned in the Pst-1-Acc-1 restriction sites of T3-T7 Bluescript plasmid (Stratagene, La Jolla, CA). The IL-2 probe was as previously described (10). The IL-6 probe corresponded to the Xba 1-Eco R1 517-bp long fragment of the human IL-6 cDNA cloned in the Xba 1-Eco R1 sites of T3-T7 Bluescript plasmid. The INF- $\gamma$ probe corresponded to the Hinf 1-Pst 1540 -bp long fragment of the human INF- $\gamma$ cDNA (11) cloned in the Bam H1-Pst 1 sites of T3-T7 Bluescript plasmid. The HIV-1 specific probe corresponded to the gag coding sequences of HIV-1 present in a Hind 3-Pst 1 DNA fragment (from bp 75 to bp 995) (12). For each probe, anti-sense and sense ${ }^{35}$ S-labeled probes were synthesized using $T 3$ or T7 polymerase according to manufacturer recommendations (Stratagene). The sense probe was used as control in each experiment and gave no positive signal (data not shown).

Hybridization procedure and combination of immunohistochemistry and in situ hybridization. They were performed as previously described (10). For a given probe, multiple sections (from four to eight) from each HIV and non HIV lymph node were hybridized and exposed in parallel. Anti-Leu2a antibody (Becton Dickinson, Mountain View, CA) was used to characterize CD8+ cells.

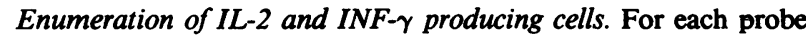
and each patient lymph node an enumeration of lymphokine producing cells was performed. To allow statistical analysis, this enumeration was realized on duplicates in two independent experiments. Thus for each probe and each patient lymph node four tissue sections were examined. Cells were scored as positive with the anti-sense probe when containing more than $\mathbf{2 0}$ grains per cell. This always corresponded to more than four times the background level. Tissue section surfaces were determined using a grid. The density of lymphokine-producing cells corresponded to the ratio between the number of lymphokineproducing cells and the surface of the corresponding tissue section. Results, expressed as the number of lymphokine-producing cells per square centimeter, represents the mean $( \pm S E M)$ density of lymphokine producing cells observed in the four sections analyzed for each probe in each patient. Student's $t$ test was used for statistical analysis.

To determine the proportion of IL-2- or INF- $\gamma$-producing cells among CD3+ cells in the different lymph node compartments (follicu- lar or interfollicular areas), we used a grid according to Garcia et al. (13). We counted for each compartment and in three serial sections the total number of IL-2-producing cells, the total number of INF- $\gamma$-producing cells, the total surface and the total CD3+ cell count, respectively. The proportion of lymphokine producing cells corresponded to the ratio between the total number of lymphokine-producing cells and that of CD3+ cells. Results expressed represent the mean number ( \pm SEM) of lymphokine producing cells $/ 10^{4} \mathrm{~T}$ cells. A paired Student's $t$ test was used for statistical analysis.

\section{Results}

Detection of HIV-1 antigens and HIV-1 RNA in HIV-1 lymph nodes. To detect the presence of HIV-1 antigens, immunostaining using an anti-p24 antibody was performed on both HIV-1 and non-HIV lymph nodes. No staining was observed in the latter (Fig. $1 A$ ). In contrast, all HIV-1 lymph nodes exhibited a clear staining of germinal centers (Fig. $1 C$ ). The reticular pattern of positivity observed suggested that the labeled cells were reticular dendritic cells.

When performing in situ hybridization experiments using an HIV-1 gag specific probe, two different patterns of hybridization were observed according to exposure time in all HIV-1 lymph nodes. After $4 \mathrm{~d}$ exposure, very rare positive cells were detected. They were located either in follicles or in interfollicular areas (not shown). When exposure was prolonged until day 20, germinal centers from all HIV infected lymph nodes were stained with the HIV-1 specific probe (Fig. $1 D$ ). As for p24 antigen expression, this labeling was diffusely distributed throughout follicles. No additional cells were detected in interfollicular areas as compared to tissue sections exposed for 4 d. No labeling of non-HIV lymph nodes was observed, regardless of time exposure (Fig. $1 B$ ).

To document a possible coinfection of HIV lymph nodes with non-HIV viruses, we performed several experiments. We first looked for the presence of herpes virus antigens by immunohistochemistry. No staining was observed in any HIV lymph node when using either an anti-HSV 1 and 2, an antiCMV, or an anti-EBV monoclonal antibody. It should be pointed out that one of the non-HIV lymph nodes (patient 10) was positively stained with the anti-EBV MAb (not shown). The absence of CMV coinfection in HIV lymph nodes was confirmed by the negativity of CMV cultures of these tissue sections. It must also be stressed that none of the lymph node from HIV infected patients displayed histological changes sug- 

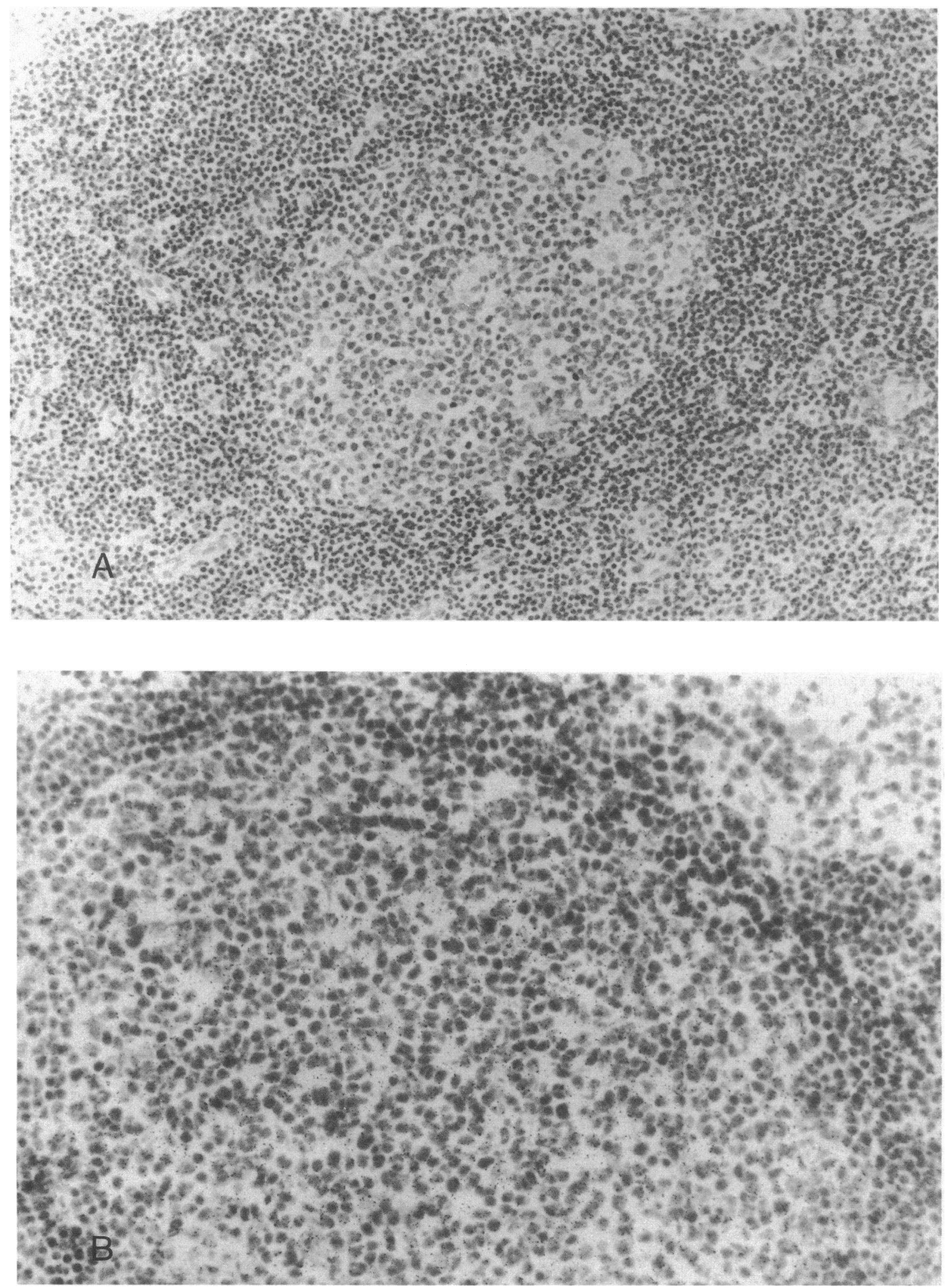

Figure 1. Detection of HIV antigens and RNA in germinal centers. Lymph node sections from non-HIV patients were analyzed for HIV p24 antigen $(A)$ and HIV-1 gag RNA $(B)$ expressions. Lymph node sections from HIV patients were analyzed in parallel for p24 antigen $(C)$ and HIV gag gene $(D)$ expressions. Exposure time of autoradiographs was for $20 \mathrm{~d}$. Sections from lymph node 1 a and 12 are shown ( $\times 200$ in $A$ and $D ; \times 500$ in $B$ and $C$ ). Follicle: $F$; interfollicular area: $I F$. 

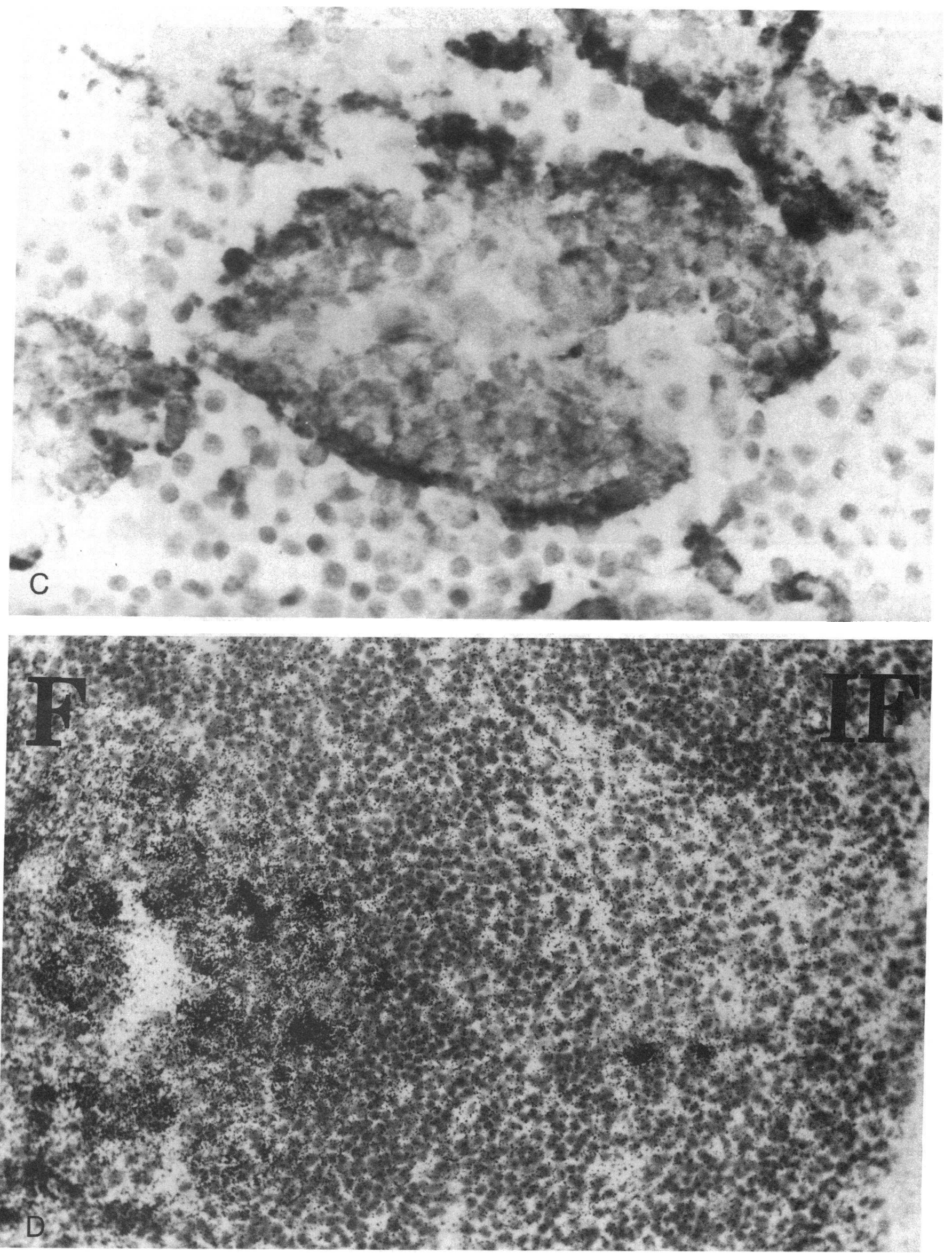

Figure 1 (Continued) 

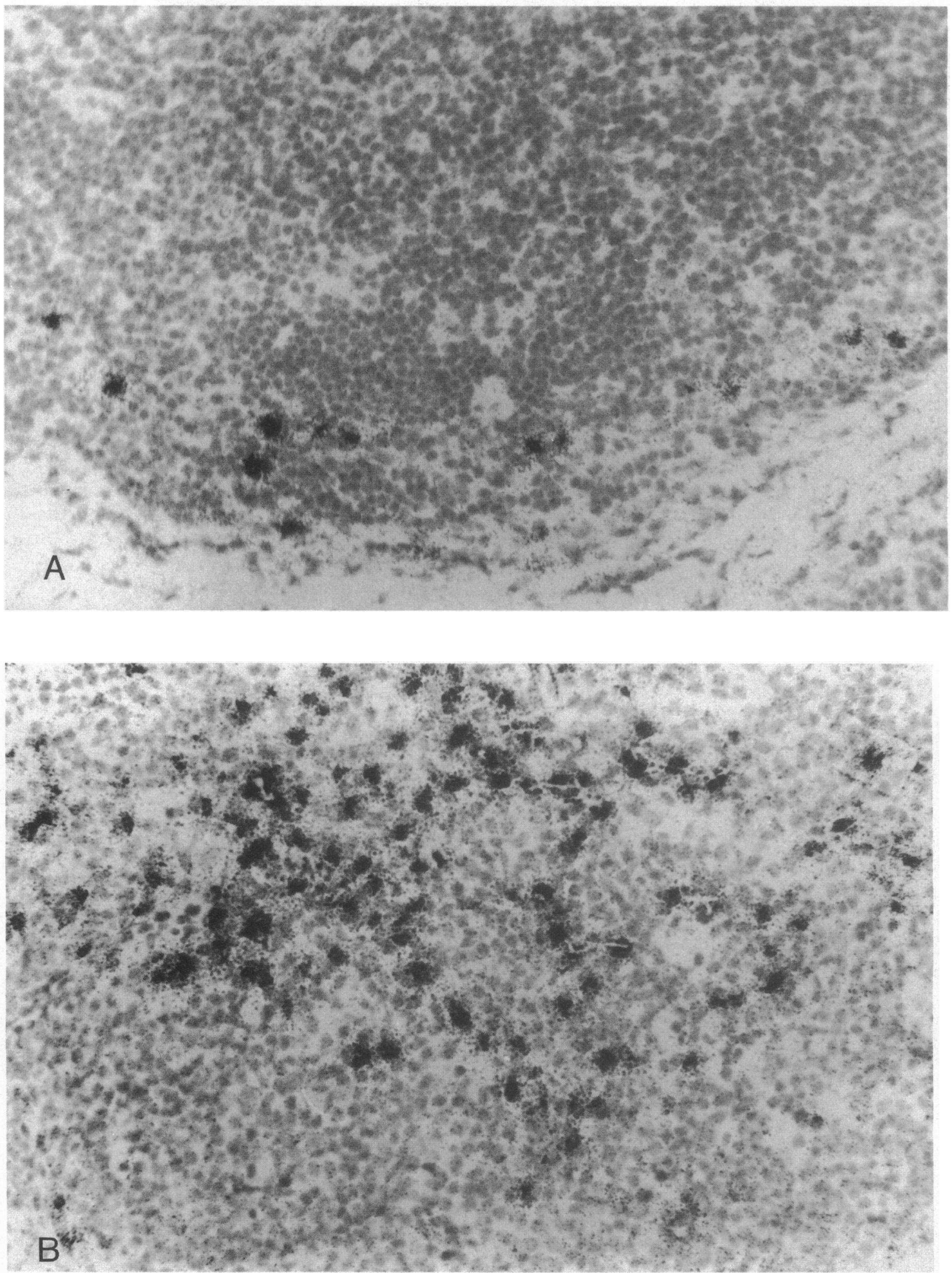

Figure 2. IL-1 $\beta$ and IL-6 production in HIV lymph nodes. Hyperplastic lymph nodes from HIV-1 infected patients were hybridized with IL-1 $\beta$ or IL-6 specific antisense probes with identical results. $(A)$ Numerous IL-1 $\beta$-producing cells in a paracortical sinus from patient 3 sections. (B) IL-6-producing cells in an interfollicular sinus from patient 5 lymph node. ( $C$ and $D$ ) IL-1 $\beta$-producing cells located in the lumen of a sinus and IL-6 producing cells in the wall of a sinus, respectively. Similar results were obtained when hybridizing non-HIV lymph nodes (not shown). $\times 200$ in $A, B$, and $C$; $\times 500$ in $D$. 

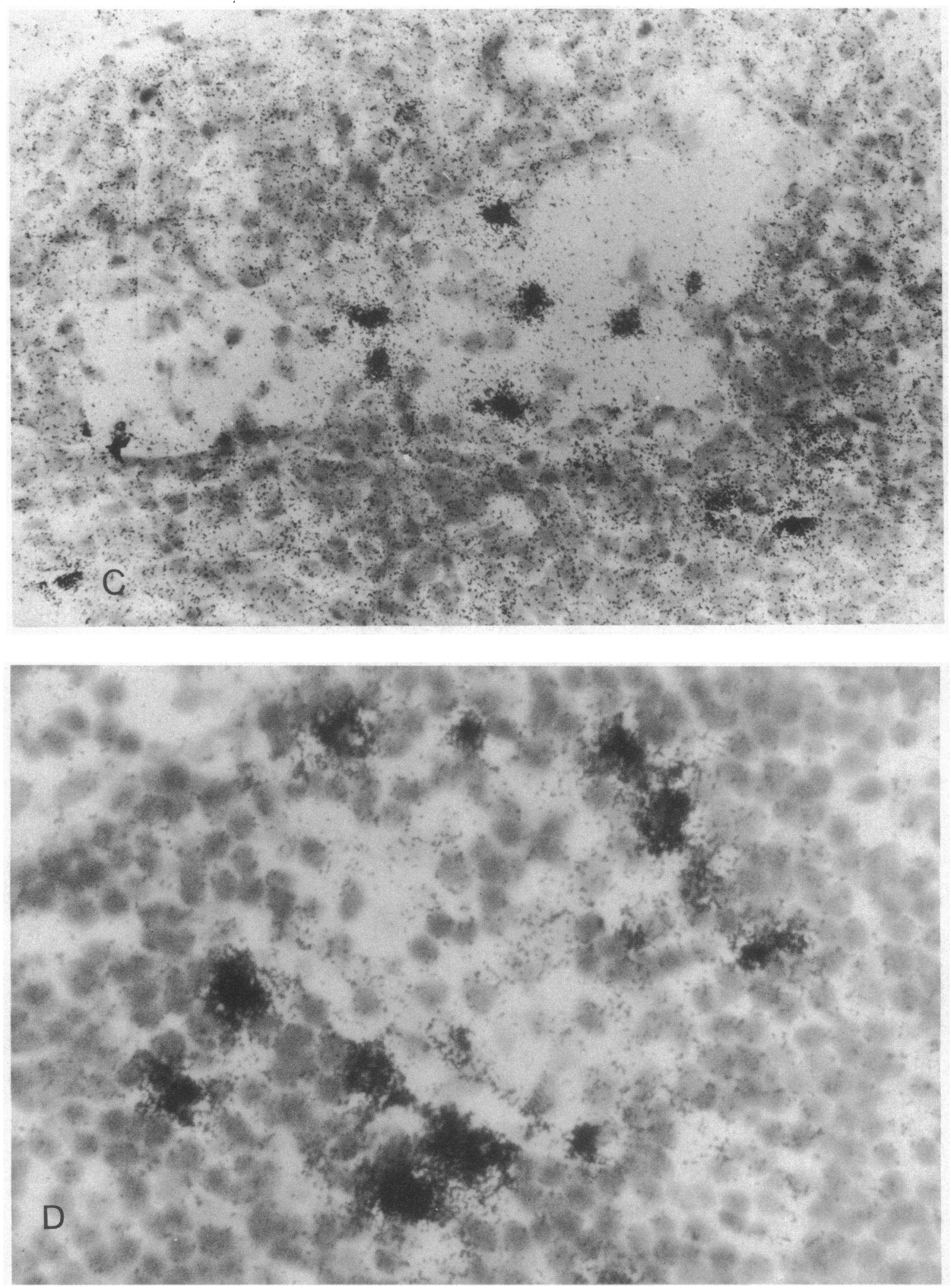

Figure 2 (Continued)

gesting an HSV, CMV, or EBV infection (6). Taken together, these findings document HIV replication in HIV lymph nodes, exclude the presence of a number of other pathogens, and show that HIV-1 core antigens and RNA are mainly located in the germinal centers.
Production of IL-1 $\beta$ and IL-6 in HIV-1 lymph nodes. The eight hyperplastic lymph node sections from HIV-1 infected patients were hybridized with an IL- $1 \beta$ specific anti-sense probe. A high number of IL- $1 \beta$ producing cells were detected in all cases. They were essentially located in subcapsular and 

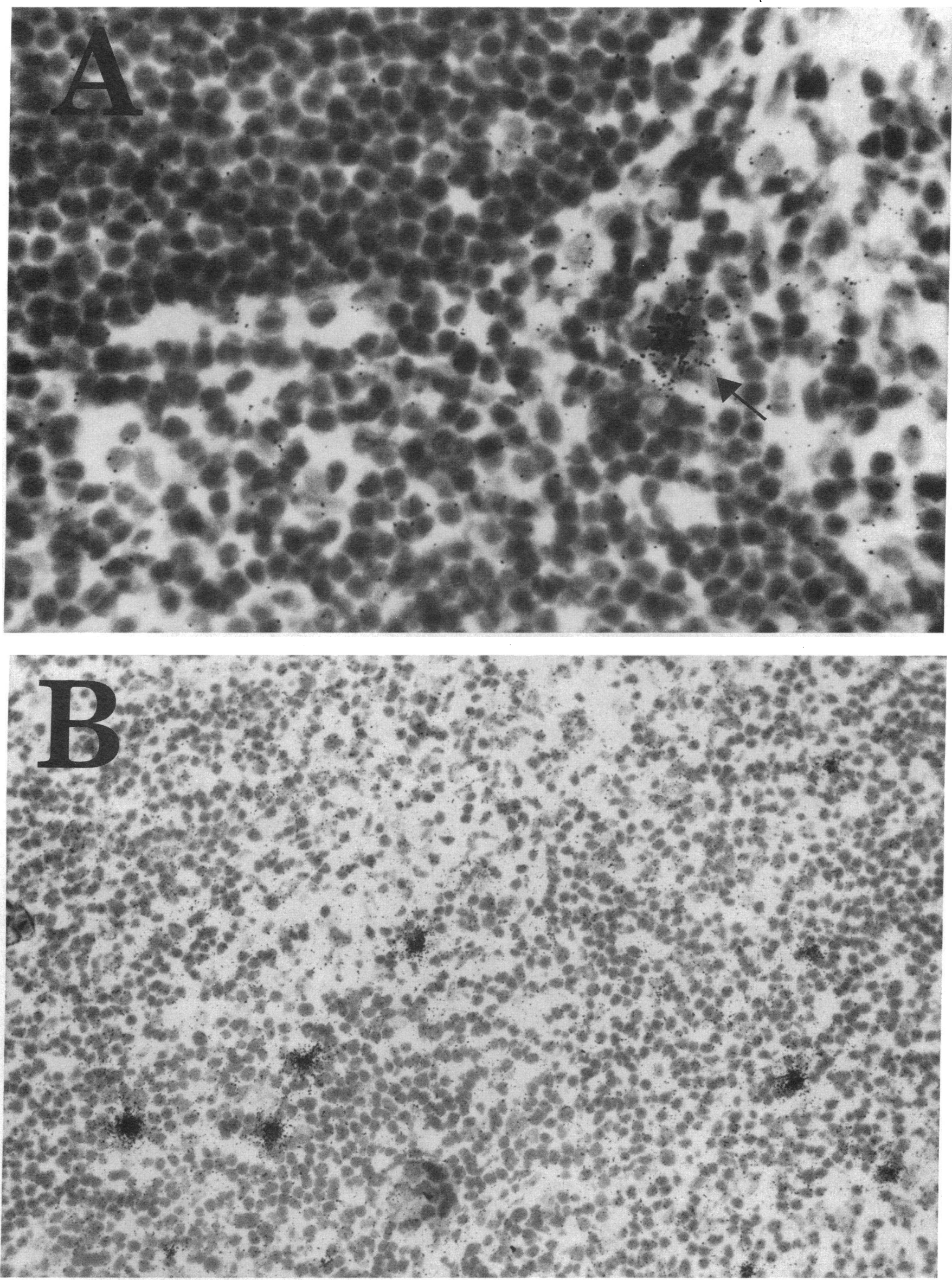
Table II. Enrichment of Lymphokine-producing Cells within Follicles

\begin{tabular}{|c|c|c|c|c|}
\hline & \multicolumn{2}{|c|}{ HIV lymph nodes } & \multicolumn{2}{|c|}{ Non-HIV lymph nodes } \\
\hline & IL-2 & IFN- $\boldsymbol{\gamma}$ & IL-2 & IFN- $\gamma$ \\
\hline $\mathbf{F}$ & $4.14( \pm 0.77)^{*}$ & $30.5( \pm 7.8)^{\ddagger}$ & $10.64( \pm 4.25)$ & $5.9( \pm 1.5)$ \\
\hline IF & $1.49( \pm 0.24)^{*}$ & $10.9( \pm 2.7)^{\ddagger}$ & $2.4( \pm 0.49)$ & $2.1( \pm 0.4)$ \\
\hline F/IF & $2.91( \pm 0.41)$ & $2.82( \pm 0.49)$ & $3.65( \pm 0.82)$ & $2.36( \pm 0.4)$ \\
\hline
\end{tabular}

The proportion of lymphokine producing CD3+ cells was determined in follicles (F) and interfollicular areas (IF) for each patient. Results are expressed as the mean ( \pm sem) of the number of lymphokine producing cells per $10^{4} \mathrm{CD} 3+$ cells detected in HIV and nonHIV lymph nodes. The ratio (F/IF) between the proportion of lymphokine producing cells/CD3 + cells present in follicles and in interfollicular areas was then determined. ${ }^{*} P<0.02$. ${ }^{\ddagger} P<0.01$.

trabecular sinuses where they were distributed in clusters (Fig. $2 A$ ). Few individual positive cells were also detected in lower amounts in follicular and interfollicular areas. There was no diffuse labeling of germinal centers.

The number and location of IL-6 producing cells were identical to those of IL- $1 \beta$ producing cells: most cells labeled with the IL-6 probe were associated in clusters within sinuses (Fig. $2 B$ ), with few solitary cells present in follicles and interfollicular areas. These IL-1 $\beta$ and IL- 6 producing cells displayed a large cell size and were present in the lumen as well as in the wall of sinuses (Fig. 2, $C$ and $D$ ). Therefore, both location and size of IL- $1 \beta$ and IL-6 producing cells suggested their macrophage-histiocyte lineage.

These IL- $1 \beta$ and IL- 6 productions were not restricted to HIV hyperplastic lymph nodes, as they were detected in similar amount and distribution in lymph node sections from six patients presenting a non-HIV-related follicular hyperplasia (not shown).

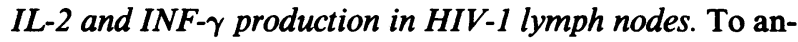
alyze the production of IL-2 and INF- $\gamma$ in HIV replicating lymph nodes, we hybridized sections from the eight HIV lymph nodes with an IL-2 and an INF- $\gamma$ specific probe. We detected both IL-2- and INF- $\gamma$-producing cells in these lymph nodes (Fig. 3). These lymphokine-producing cells were scattered in follicular and interfollicular areas. We observed a similarly located IL-2 and INF- $\gamma$ synthesis in the six non-HIV hyperplastic lymph nodes (see Fig. 4 and Table II).

To quantitate the level of lymphokine production, we determined the density of IL-2- and INF- $\gamma$-producing cells in the different lymph nodes. To this end, we analyzed the number of lymphokine-producing cells and the surface of the corresponding lymph node section. HIV and non-HIV sections were studied in parallel as detailed in Methods. Two main observations could be drawn from these results (Fig. 4). First, the density of IL-2-producing cells was in the same range in HIV and in non-HIV lymph nodes: as a mean there were 2.7 times less IL-2 producing cells in HIV than in non-HIV lymph nodes, this difference being not statistically significant. This
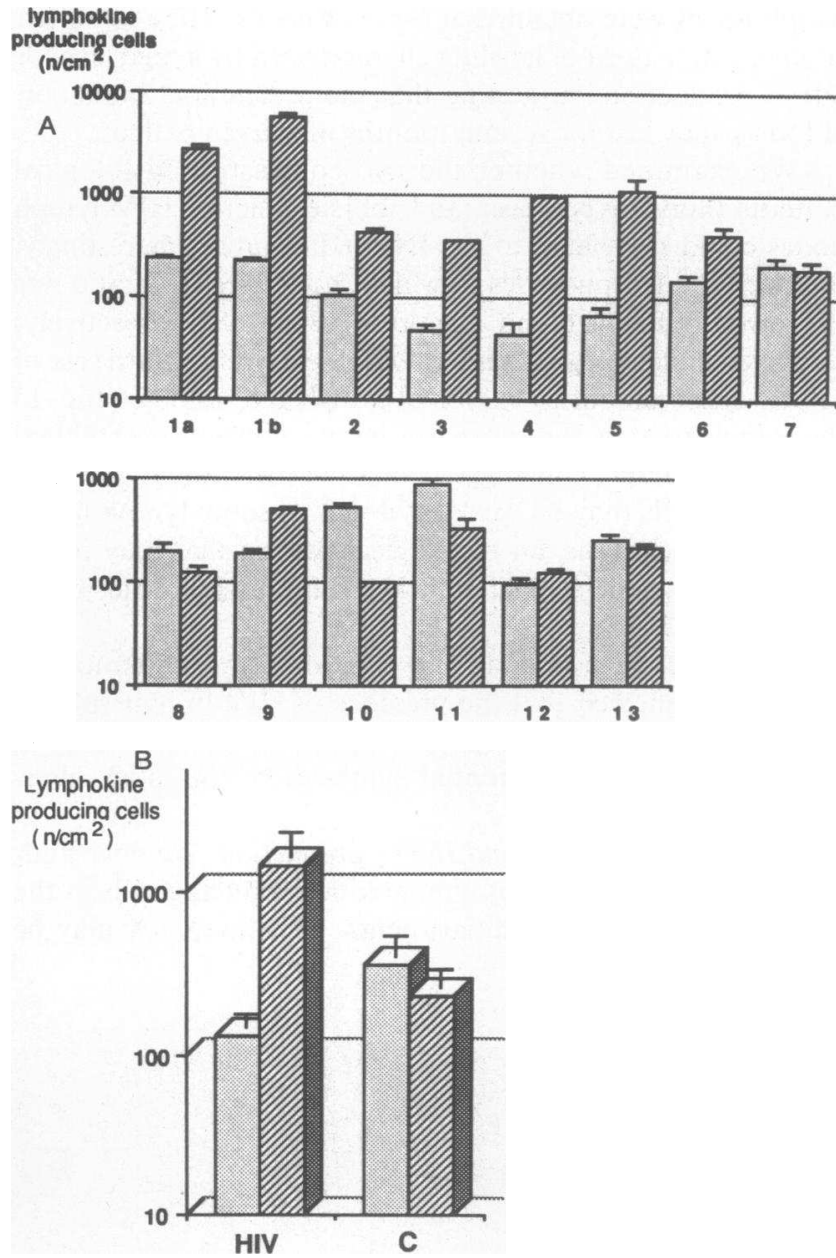

Figure 4. IL-2 and INF- $\gamma$-producing cells density in HIV and nonHIV lymph nodes. $(A)$ The density of IL-2 (empty columns) and of INF- $\gamma$ (hatched columns) producing cells was determined in the eight HIV replicating lymph nodes (1a-7) and in the six control hyperplastic lymph nodes (8-13). Lymph nodes la to 4 displayed a florid hyperplasia, whereas lymph nodes 5 to 7 exhibited follicular regression. Results are expressed as the number of lymphokine-producing cells/ $\mathrm{cm}^{2}$ of tissue section $( \pm$ SEM). $(B)$ The mean density ( \pm SEM) of IL-2 (empty columns)- and INF- $\gamma$ (hatched columns)-producing cells in HIV and control $(C)$ lymph nodes was determined.

shows that, at least in HIV patients presenting PGL, the production of IL-2 in a lymphoid organ is not dramatically affected by the replication of HIV at this site. The second conclusion was that INF- $\gamma$ production was clearly increased in HIV lymph nodes. The mean density of INF- $\gamma$ producing cells was 6.3 times higher in HIV lymph nodes than it was in nonHIV lymph nodes. This difference was not statistically different. However, when the ratio between the number of INF- $\gamma$ and IL-2-producing cells present in each lymph node was examined, it was dramatically increased in HIV lymph nodes as compared with that of non-HIV lymph nodes (11.43 \pm 3.2 and $0.97 \pm 0.36$, respectively, $P<0.02$ ). In patient 1 , two different

Figure 3. IL-2 and INF- $\gamma$ production in HIV lymph nodes. Lymph nodes from HIV-1 infected patients were hybridized with an IL-2-specific antisense probe $(\times 500)$. Scattered IL-2-producing cells were detected in both follicles and interfollicular areas $(A)$. INF- $\gamma$-producing cells were also detected in all HIV patients $(B, \times 200)$. 
lymph nodes were obtained at 6-mo intervals. They exhibited an identical pattern of labeling characterized by a high level of INF- $\gamma$ production, suggesting that the preferential induction of INF- $\gamma$ may last for several months in a given patient.

We examined whether the two contrasting histological patterns (florid hyperplasia and follicle lysis) of HIV lymph nodes could be related to the INF $\gamma /$ IL-2 ratio. Interestingly, the two HIV lymph nodes in which the INF- $\gamma / \mathrm{IL}-2$ ratio was the lowest (patients 6 and 7 , ratio $=2.8$ and 0.9 , respectively) displayed an histological pattern of follicle lysis. A third case of follicle lysis (patient 5) exhibited a high INF- $\gamma / \mathrm{IL}-2$ ratio, to the same extent as the other five lymph nodes that exhibited florid hyperplasia. This suggests that the enrichment in INF- $\gamma$ producing cells may be weak or absent in some lymph nodes showing follicle lysis, an histological pattern that may represent a subsequent step of follicle evolution following florid hyperplasia (14).

Therefore, the quantitative evaluation of lymphokine-producing cells showed that the presence of HIV in hyperplastic lymph nodes was associated with the production of both IL-2 and INF- $\gamma$ with a preferential synthesis of the latter interleukin.

Localization of IL-2 and INF- $\gamma$ production. We next studied the fine distribution of lymphokine producing cells in the different lymph node compartments. This approach may be indicative of the site of $T$ cell activation in these tissues. In this purpose, we determined in the different compartments of 3 serial sections the number of IL- 2 and INF- $\gamma$ producing cells and that of CD3+ cells (Table II). We evidenced a selective enrichment of lymphokine-producing cells in follicles as compared to interfollicular areas. The higher proportion of IL-2 and IFN- $\gamma$ synthetizing $T$ cells in follicles was observed in both HIV and non-HIV lymph nodes. Therefore, germinal centers may be the preferential site of $T$ cell activation regardless of the nature of the stimulant. This could be related to the function of follicular dendritic cells as antigen-presenting cells.

Characterization of INF- $\gamma$-producing cells. From the previous results, it appears that the immune reaction induced by HIV replication in hyperplastic lymph nodes is characterized by an increased level of INF- $\gamma$ production. As infiltration of germinal centers with $\mathrm{CD} 8+$ cells is known to be a specific feature of HIV replicating lymph nodes (reviewed in 14), we wished to determine whether this high level of INF- $\gamma$ production arose from this $T$ cell subpopulation. When simultaneously analyzing the presence of CD8 antigens and of INF- $\gamma$ mRNA containing cells by combining immunohistochemistry and in situ hybridization, we observed that many germinal center infiltrating CD8+ cells indeed produced INF- $\gamma$ (Fig. 5 ). Thus, the elevated INF- $\gamma$ production observed in HIV lymph nodes is at least partially related to the specific CD8+ infiltra-

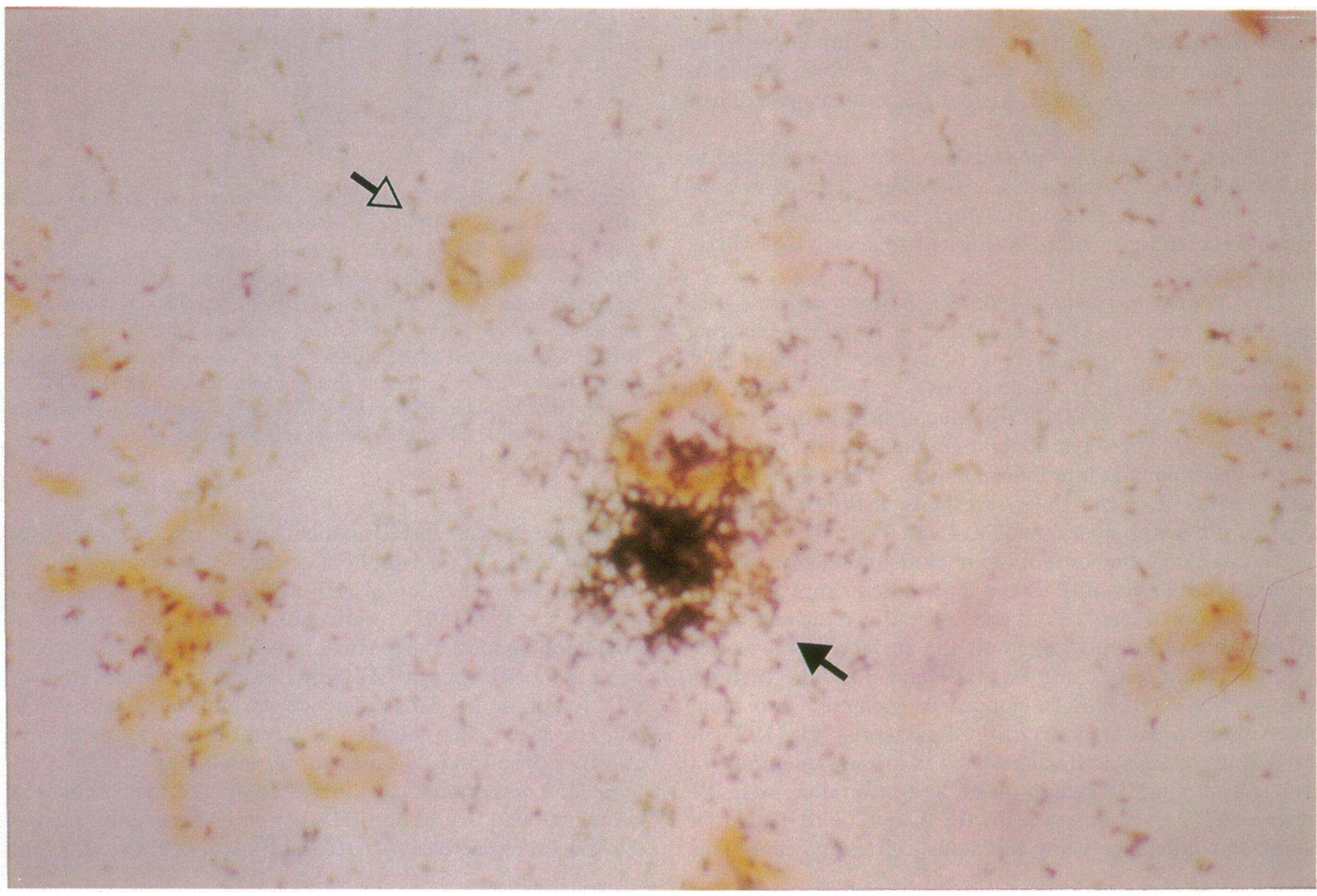

Figure 5. Production of INF- $\gamma$ by CD8+ cells. Lymph nodes sections from patient 2 were subsequently labeled with an anti-CD8 monoclonal antibody and hybridized with an INF- $\gamma$ specific antisense probe, allowing the vizualization of CD8 + INF- $\gamma$ producing cells. $\rightarrow$ : a CD8+ cell which do not produce INF- $\gamma . \rightarrow:$ an INF- $\gamma$ producing CD8+ cell. $\times 1250$. Identical results were obtained with patient 1 lymph node sections. 
tion of their germinal centers. As these cells are in close contact with cells expressing HIV antigens and RNA (see Fig. 1), $\mathrm{CD} 8+\mathrm{T}$ cell activation and INF- $\gamma$ synthesis may be triggered by viral antigens.

\section{Discussion}

In the present work we studied using in situ hybridization the production of interleukins in hyperplastic lymph nodes from HIV-1 infected patients presenting PGL. We compared these productions with those observed in non-HIV-related hyperplastic lymph nodes.

When analyzing the in situ production of IL- $1 \beta$ and IL-6 in HIV lymph nodes, we observed a high number of IL- $1 \beta$ - and IL-6-producing cells, essentially located in clusters within sinuses. Very few scattered individual cells were observed in follicles and interfollicular areas. The distribution and the apparent size of these IL- $1 \beta$ - and IL-6-producing cells suggest their macrophage-histiocyte origin. As monocytoid cells expressing B lymphocyte antigens have recently been identified in sinuses of hyperplastic lymph nodes $(15,16)$, we cannot formally exclude that the IL- $1 \beta$ and IL- 6 productions we detected arose from this cell population. However, it should be stressed that cells hybridizing with the IL- $1 \beta$ or the IL- 6 probe were rarely found in germinal centers, an area that is mainly constituted of activated B lymphocytes and reticular dendritic cells. This indicates that the production of IL- $1 \beta$ and IL- 6 by these latter cell populations, if any, must be marginal. The presence of positive cells in the wall of the sinuses also suggests that sinus endothelial cells may participate to this IL- $1 \beta$ and IL-6 production. To our knowledge no report is presently available regarding the in situ production of cytokines in nonHIV hyperplastic lymph nodes. The amount and location of IL-1 $\beta$ - and IL-6-producing cells we detected in these tissues was strikingly similar to that observed in HIV lymph nodes. The production of monokines (as well as the hyperplastic pattern of the lymph nodes) is suggestive of an immune activation of these lymphoid organs, which is probably directly related to the presence of HIV in the case of HIV-replicating lymph nodes. Indeed we found no evidence of coinfection of these latters with non-HIV viruses. HIV has been shown to stimulate the in vitro production of IL-1 and IL-6 $(17,18)$, and a similar phenomenon probably occurs in vivo, as unstimulated purified blood monocytes from HIV-infected patients produce increased levels of IL-1 (19).

We also detected IL-2-producing cells in HIV lymph nodes. These cells were located both in follicular and interfollicular areas. They were present in low amounts, in the range of 1 to $7 \mathrm{IL}-2$ producing cells $/ 10^{4} \mathrm{CD} 3+$ cells. This IL-2 production can be ascribed to $\mathrm{T}$ cell activation for the following reasons: (a) such an IL-2 production is virtually absent in normal thymus sections (Emilie, D., et al., submitted for publication) (b) the density of IL-2 producing cells in HIV lymph nodes is in the same range of that found in lymphoid organs involved in an immune reaction, including non-HIV hyperplastic lymph nodes (this work), tumor-induced immune response $(10,19 a)$ or hyperplastic thymuses from myasthenic patients (Emilie, D., et al., submitted for publication). The detection of virtually normal amounts of IL-2-producing cells in HIV lymph nodes contrasts with results obtained from previous studies that showed a profound impairment in the ability of in vitro activated peripheral blood lymphocytes from HIV patients to produce IL-2 (20-24). However, this decreased production of IL-2 is no more found when studied at the cellular subset level (24). Moreover, in vitro HIV infected cell lines constitutively transcribe IL-2 gene and produce increased levels of IL-2 mRNA when stimulated in vitro with a mitogen (25). It should also be noted that none of the patients analyzed in this study displayed a profound immune defect, as none of them presented opportunistic infection and only one had a major circulating CD4+ $T$ cell depletion. Finally, the absence of IL-2 production impairment in PGL presenting patients may be explained by the fact that the production of IL-2 (a lymphocyte growth factor) may be required for the development of lymph node hyperplasia, which does not occur in all HIV patients and usually disappears in the latest stage of the disease. Taken together, we conclude that HIV-1 replication by itself does not inhibit IL-2 production in vivo, at least in patients exhibiting PGL.

HIV lymph nodes displayed numerous INF- $\gamma$ mRNA containing cells. This result contrasts with reports of decreased in vitro production of this interleukin by unfractionated mononuclear cells from HIV-infected patients $(24,26)$. However, as for IL-2 synthesis, this INF- $\gamma$ production impairment is not found when the production of cellular subsets is analyzed (24). Although we cannot exclude a dissociation (not described yet) between the production of INF- $\gamma$ mRNA and that of the corresponding protein, our results strongly suggest that the in vivo synthesis of INF- $\gamma$ is conserved in HIV patients presenting PGL. This may be directly related to their preserved IL-2 production, as IL-2 can stimulate the in vitro synthesis of INF- $\gamma$ by peripheral blood lymphocytes from normal (27) and AIDS (23) subjects. Moreover infusion of IL-2 induces the appearance of circulating INF- $\gamma$ in AIDS patients (28).

Quantitative analysis indicated that the amount of INF- $\gamma$ producing cells was in fact increased in most HIV lymph nodes when compared with that of IL-2-producing cells. This contrasted with results from non-HIV lymph nodes in which the number of INF- $\gamma$-producing cells was similar to that of IL-2producing cells. The present results can also be compared with those from our recent study of 21 follicular lymphomas (19a). In this study we found that the mean number of IL-2producing cells was higher than that of INF- $\gamma$ producing cells (the ratio between IL- 2 and INF- $\gamma$ producing cells was $2.69 \pm 0.84)$. These data underline the peculiar pattern observed in HIV lymph nodes. Thus distinct patterns of interleukin production by activated $\mathrm{T}$ cells may occur in different in vivo situations, HIV preferentially stimulating INF- $\gamma$ production.

Germinal centers may be considered as a critical site for the interactions between HIV and the host immune system. They contain high amounts of HIV core antigens, as evidenced in several studies by the positivity of immunolabeling with antiHIV core antibodies (14, 29-35 and this work). The reticular pattern of anti-p24 staining indicates that the network of follicular dendritic cells may be an important reservoir of HIV antigens at this site. This is supported by electron microscopy studies in which HIV particles were only found in germinal centers, in close contact with processes of follicular dendritic cells $(31,36-39)$. When performing in situ hybridization we observed two kinds of labeling. Very rare HIV RNA containing cells located both in follicles and in interfollicular areas 
were detected after short exposure time, as already reported in similar conditions or when using nonradioactive probes $(29$, $35,40,41)$. A diffuse labeling of germinal centers could also be evidenced in our hands provided that exposure time was prolonged. Such a delayed positivity of germinal centers has already been noted by Biberfeld et al. (40). The pattern observed in this latter case is suggestive of follicular dendritic cell labeling $(14,40)$. It may be relevant to either HIV replication in this cell population or to a viral trapping. Taken together, these different approaches indicate that germinal centers represent the major lymph node compartment containing HIV antigens, RNA, and particles.

Follicles of HIV replicating lymph nodes are infiltrated with high numbers of CD8+ cells (reviewed in 14). As freshly isolated anti-HIV CTL from HIV-infected patients are essentially contained in this CD8+ cell subset (42-46), CD8+ cells present in germinal centers may be involved in an anti-HIV cytotoxic $T$ cell response. However no direct evaluation of their function has been performed so far. We here show that IFN- $\gamma$ production may be an important functional characteristic of these cells. CD8+ cells have recently been shown to inhibit the in vitro replication of HIV upon direct contact with virus replicating cells $(45,47)$, and INF- $\gamma$ production may be involved in this phenomenon (48). Our present report is the first direct demonstration that the partners for such an interaction (HIV containing dendritic cells and IFN- $\gamma$ producing CD8+ cells) are present within germinal centers of HIV hyperplastic lymph nodes. Larger studies are required to determine whether the pattern of cytokine production in HIV lymph nodes is a critical factor in the course of the disease leading to the relative control of viral replication, to the development of follicle lysis and that of major immune dysfunction.

\section{Acknowledgments}

J. M. Dayer, C. Vaquero, and R. Falkoff are acknowledged for the gift of IL-1 $\beta$, IL-6, INF- $\gamma$, and IL-2 cDNA probes, and E. Dussaix for performing CMV cultures.

Supported by Agence Nationale de Recherche sur le SIDA and Université Paris-Sud. Dr. Emilie was partially supported by the Fonds d'Etude du Corps Medical des Hôpitaux de Paris.

\section{References}

1. Melbye, M., R. Biggar, P. Ebbesen, C. Neuland, J. J. Goedert, V. Faber, I. Lorenzen, P. Skinhoj, R. C. Gallo, and W. A. Blattner. 1986. Long-term seropositivity for human $\mathrm{T}$ lymphotropic virus type III in homosexual men without the acquired immunodeficiency syndrome development of immunologic and clinical abnormalities. Ann. Intern. Med. 104:496-500.

2. Fauci, A. S. 1988. The human immunodeficiency virus: infectivity and mechanisms of pathogenesis. Science (Wash. DC) 239:617622.

3. Ho, D. D., R. J. Pomerantz, and J. C. Kaplan. 1987. Pathogenesis of infection with human immunodeficiency virus. N. Engl. J. Med. 317:278-283.

4. Siliciano, R. F., T. Lawton, C. Knall, R. W. Karr, P. Berman, T. Gregory, and E. L. Reinherz. 1988. Analysis of host-virus interactions in AIDS with anti-gp120 T cell clones: effect of HIV sequence variation and a mechanism for CD4+ cell depletion. Cell. 54:561-575.

5. Lanzavecchia, A., E. Roosnek, T. Gregory, P. Berman, and S. Abrignani. 1988. T cells can present antigens such as HIV gp120 targeted to their own surface molecules. Nature (Lond.). 334:530-532.
6. Stansfeld, A. G. 1985. Viral diseases. In Lymph Node Biopsy Interpretation. A. G. Stanfield, editor. Churchill Livingstone, Edinburgh. 128-141.

7. Mason, D. Y., and R. E. Sammons. 1979. The labelled antigen method of immunoenzymatic staining. J. Histochem. Cytochem. 27:832-840.

8. Alpert, G., M. C. Mazeron, R. Colimon, and S. A. Plotkin. 1985. Rapid detection of human cytomegalovirus in the urines of humans. $J$. Infect. Dis. 152:631-633.

9. March, C. J., B. Mosley, A. Larsen, D. P. Cerretti, G. Braedt, V. Price, S. Gillis, C. S. Henney, S. R. Kronheim, K. Grabstein, P. J. Conlon, T. P. Hopp, and D. Cosman. 1985. Cloning, sequence and expression of two distinct human interleukin-1 complementary DNAs. Nature (Lond.). 315:641-647.

10. Peuchmaur, M., D. Emilie, M. C. Crevon, P. Solal-Céligny, M. C. Maillot, G. Lemaigre, and P. Galanaud. IL-2 mRNA expression in Tac positive malignant lymphomas. Am. J. Pathol. 136:383-390.

11. Sancéau, J., P. Sondermeyer, F. Béranger, and R. Falcoff. 1987. Intracellular human gamma-interferon triggers an antiviral state in transformed murine L cells. Proc. Natl. Acad. Sci. USA. 84:29062910.

12. Vazeux, R., N. Brousse, and A. Jarry. 1987. AIDS subacute encephalitis: identification of HIV-infected cells. Am. J. Pathol. 126:403-410.

13. Garcia, C. F., L. M. Weiss, J. Lowder, C. Komoroshke, M. P. Link, R. Levy, and R. A. Warnke. 1987. Quantitation and estimation of lymphocytes subsets in tissue sections. Comparison with flow cytometry. Am. J. Pathol. 87:470-477.

14. O'hara, C. J. 1989. Lymphoid system. In Pathology and Pathophysiology of AIDS and HIV-related Diseases. S. J. Harawi and C. J. O'Hara, editors. Chapman and Hall Medical Publishers, London. 136-183.

15. Sheibani, K., R. M. Fritz, C. D. Winberg, J. S. Burke, and H. Rappaport. 1984. Monocytoid cells in reactive follicular hyperplasia with and without multifocal histiocytic reaction: an immunohistochemical study of 21 cases of toxoplasmic lymphadenitis. Am. J. Clin. Pathol. 27:453-458.

16. Stein, H., K. Lennert, and D. Y. Mason. 1984. Immature sinus histiocytes. Their identification as a novel B cell population. Am. J. Pathol. 117:44-52.

17. Wahl, L. M., M. L. Corcoran, S. M. Pyle, L. O. Arthur, A. Harel-Bellan, and W. L. Farrar. 1989. Human immunodeficiency virus glycoprotein (gp120) induction of monocyte arachidonic acid metabolites and interleukin 1. Proc. Natl. Acad. Sci. USA. 86:621-625.

18. Nakajima, K., O. Martinez-Maza, T. Hirano, E. C. Breen, P. G. Nishanian, J. F. Salazar-Gonzalez, J. L. Fahey, and T. Kishimoto. 1989. Induction of IL-6 (B cell stimulatory factor-2/IFN beta2) production by HIV. J. Immunol. 142:531-536.

19. Roux-Lambard, P., C. Modoux, A. Cruchaud, and J. M. Dayer. 1989. Purified blood monocytes from HIV 1 -infected patients produce high levels of TNF alpha and IL-1. Clin. Immunol. Immunopathol. 50:374-384.

19a. Peuchmaur, M., D. Emilie, M.-C. Crevon, N. Brousse, P. Gaulard, M.-F. D'Agay, P. Galanaud, and P. Solal-Celigny. 1990. Interleukin-2 and interferon-gamma production in follicular lymphomas. Am. J. Clin. Pathol. In press.

20. Ciobanu, N., K. Welte, G. Kruger, S. Venuta, J. Gold, S. P. Geldman, C. Y. Wang, B. Koziner, M. A. S. Moore, B. Safai, and R. Mertelsmann. 1983. Defective T cell response to PHA and mitogenic monoclonal antibodies in male homosexuals with acquired immunodeficiency syndrome and its in vitro correction by interleukin $2 . J$. Clin. Immunol. 3:332-341.

21. Fauci, A. S. 1987. AIDS: immunopathogenic mechanisms and research strategies. Clin. Res. 35:503-510.

22. Maggi, E., D. Macchia, P. Parronchi, M. Mazzetti, A. Ravina, D. Milo, and S. Romagnani. 1987. Reduced production of interleukin 2 and interferon-gamma and enhanced helper activity for IgG synthe- 
sis by cloned CD4+ T cells from patients with AIDS. Eur. J. Immunol. 17:1685-1690.

23. Murray, H. W., K. Welte, J. L. Jacobs, B. Y. Rubin, R. Mertelsmann, and R. B. Roberts. 1985. Production of and in vitro response to interleukin 2 in the acquired immunodeficiency syndrome. J. Clin. Invest. 76:1959-1964.

24. Lane, H. C., J. M. Depper, W. C. Greene, G. Whalen, T. A. Waldmann, and A. S. Fauci. 1985. Qualitative analysis of immune function in patients with the acquired immunodeficiency syndrome. N. Engl. J. Med. 313:79-83.

25. Arya, S. K., and R. C. Gallo. 1985. Human T-cell growth factor (interleukin 2) and gamma-interferon genes: expression in human $\mathrm{T}$ lymphotropic virus type III- and type I-infected cells. Proc. Natl. Acad. Sci. USA. 82:8691-8695.

26. Murray, H. W., B. Y. Rubin, H. Masur, and R. B. Roberts. 1984. Impaired production of lymphokines and immune (gamma) interferon in the acquired immunodeficiency syndrome. $N$. Engl. J. Med. 310:883-888.

27. Reem, G. H., and N. H. Yeh. 1984. Interleukin 2 regulates expression of its receptor and synthesis of gamma interferon by human T lymphocytes. Science. 235:429-430.

28. Murray, H. W., J. DePamphilis, and R. T. Schooley. 1988. Circulating interferon gamma in AIDS patients treated with interleukin 2. N. Engl. J. Med. 318:1538-1539.

29. Baroni, C. D., F. Pezzella, M. Pessella, B. Macchi, D. Vitolo, S. Uccini, and L. P. Rugo. 1988. Expression of HIV in lymph node cells of LAS patients. Am. J. Pathol. 133:498-506.

30. Tenner-Racz, K., M. Bofill, A. Schulz-Meyer, M. Dietrich, P. Kern, J. Weber, A. J. Minching, F. Veronese-Dimarzo, M. Popovic, D. Klatzmann, J. C. Gluckman, and G. Janossy. 1986. HTLV-III/LAV viral antigens in lymph nodes of homosexual men with persistent generalized lymphadenopathy and AIDS. Am. J. Pathol. 123:9-15.

31. Baroni, C. D., F. Pezzella, M. Mirolo, L. P. Ruco, and G. B. Rossi. 1986. Immunohistochemical demonstration of p24 HTLV III major core protein in different cell types within lymph nodes from patients with lymphadenopathy syndrome (LAS). Histopathology. 10:5-13.

32. Biberfeld, P., A. Ost, A. Porwit, B. Standstedt, G. Pallesen, G. Böttiger, L. Morfeldt-Mansson, and G. Biberfeld. 1987. Histopathology and immunohistology of HTLV-III/LAV related lymphadenopathy and AIDS. Acta Pathol. Microbiol. Immunol. Scand. Sect. A. 95:47-65.

33. Pekovic, D. D., M. Gornitsky, D. Ajdukovic, J. M. Dupuy, J. P Chausseau, J. Michaud, N. Lapointe, N. Gilmore, C. Tsoukas, G. Zwadlo, and M. Popovic. 1987. Pathogenicity of HIV in lymphatic organs of patients with AIDS. J. Pathol. 152:31-35.

34. Ward, J. M., T. J. O'Leary, G. B. Baskin, R. Benveniste, C. A Harris, P. L. Nara, and R. H. Rhodes. 1987. Immunohistochemical localization of human and simian immunodeficiency viral antigens in fixed tissue sections. Am. J. Pathol. 127:199-205.

35. Schuurman, H. J., J. A. Willy, R. Broekhuizen, and J. Goudsmit. 1988. Expression of RNA and antigens of human immunodefi- ciency virus type-1 (HIV-1) in, lymph nodes from HIV-1 infected individuals. Am. J. Pathol. 133:516-524.

36. Le Tourneau, A., J. Audouin, J. Diebold, C. Marche, V. Tricottet, and M. Reynes. 1986. LAV-like viral particles in lymph node germinal centers in patients with the persistent lymphadenopathy syndrome and the acquired immunodeficiency syndrome-related complex: an ultrastructural study of 30 cases. Hum. Pathol. 17:1047-1053.

37. Armstrong, J. A., and R. Horne. 1984. Follicular dendritic cells and retrovirus-like particles in AIDS-related lymphadenopathy. Lancet. ii:370-372

38. Tenner-Racz, K., P. Racz, M. Dietrich, and P. Kern. 1985. Altered follicular dendritic cells and virus-like particles in AIDS and AIDS-related lymphadenopathy. Lancet. i:105-106.

39. Tenner-Racz, K., P. Racz, J. C. Gluckman, and M. Popovic. 1988. Cell-free HIV in lymph nodes of patients with AIDS and generalized lymphadenopathy. N. Engl. J. Med. 318:49-50.

40. Biberfeld, P., K. J. Chayt, L. M. Marselle, G. Biberfeld, R. C. Gallo, and M. E. Harper. 1988. HTLV-III expression in infected lymph nodes and relevance to pathogenesis of lymphadenopathy. Am. J. Pathol. 123:436-442.

41. Harper, M. E., L. M. Marselle, R. C. Gallo, and F. Wong-Staal. 1986. Detection of lymphocytes expressing human T-lymphotropic virus type III in lymph nodes and peripheral blood from infected individuals by in situ hybridization. Proc. Natl. Acad. Sci. USA. 83:772-776.

42. Sehti, K. K., H. Näher, and I. Strochman. 1988. Phenotypic heterogeneity of cerebrospinal fluid-derived HIV-specific and HLA-restricted cytotoxic T-cell clones. Nature (Lond.). 335:178-181.

43. Walker, B. D., S. Chakrabarti, B. Moss, T. J. Paradis, T. Flynn, A. G. Durno, R. S. Blumberg, J. C. Klaplan, M. S. Hirsch, and R. T. Schooley. 1987. HIV-specific cytotoxic T lymphocytes in seropositive individuals. Nature (Lond.). 328:345-348.

44. Plata, F., B. Autran, L. P. Martins, S. Wain-Hobson, M. Raphael, C. Mayaud, M. Denis, J. Guillon, and P. Debré. 1987. AIDS virus-specific cytotoxic T lymphocytes in lung disorders. Nature (Lond.). 328:348-351.

45. Walker, C. M., D. J. Moody, D. P. Stites, and J. A. Levy. 1986. CD8+ lymphocytes can control HIV infection in vitro by suppressing virus replication. Science (Wash. DC). 234:1563-1566.

46. Langlade-Demoyen, P., F. Michel, A. Hoffenbach, E. Vilmer, G. Dadaglio, F. Garicia-Pons, C. Mayaud, B. Autran, S. Wain-Hobson, and F. Plata. 1988. Immune recognition of AIDS virus antigens by human and murine cytotoxic T lymphocytes. J. Immunol. 141:19491957.

47. Tsubota, H., C. I. Lord, D. I. Watkins, C. Morimoto, and N. L. Letvin. 1989. A cytotoxic $T$ lymphocyte inhibits acquired immunodeficiency syndrome virus replication in peripheral blood lymphocytes. J. Exp. Med. 169:1421-1434.

48. Kornbluth, R. S., P. S. Oh, J. R. Muniq, P. H. Cleveland, and D. D. Richman. 1989. Interferon and bacterial lipopolysaccharide protect macrophages from productive infection by human immunodeficiency virus in vitro. J. Exp. Med. 169:1137-1151. 